\title{
Lipid dynamics during the embryonic development of Plesionika martia martia (Decapoda; Pandalidae), Palaemon serratus and P. elegans (Decapoda; Palaemonidae): relation to metabolic consumption
}

\author{
S. Morais ${ }^{1}$, L. Narciso ${ }^{1, *}$, R. Calado ${ }^{1}$, M. L. Nunes $^{2}{ }^{,}$R. Rosa $^{2}$ \\ ${ }^{1}$ Departamento de Zoologia e Antropologia, Faculdade de Ciências da Universidade de Lisboa, Laboratório Marítimo da \\ Guia, Estrada do Guincho, Forte N.S. da Guia, 2750-642 Cascais, Portugal \\ ${ }^{2}$ Departamento de Inovação Tecnológica e Valorização dos Produtos da Pesca, IPIMAR, Avenida de Brasília, \\ 1449-006 Lisboa, Portugal
}

\begin{abstract}
The present study examines the changes in volume and lipid biochemistry during the embryonic development of 3 temperate caridean species - Plesionika martia martia, Palaemon serratus and $P$. elegans - with similar reproductive strategies but occupying different ecological niches. Egg volume, water content and lipid embryonic metabolism are analysed and discussed in relation to early life history and environmental conditions. An increase in egg volume and water content during embryogenesis was noted in all species, although it was larger in P. serratus. $P$. serratus also had the largest eggs, followed by $P$. elegans and $P$. martia martia. The quantitatively most important fatty acids (FA) in the eggs are the saturates (SFA) 14:0, 16:0 and 18:0, the monounsaturates (MUFA) 16:1(n-7), 18:1(n-9) and 18:1(n-7), and the polyunsaturates (PUFA) 18:2(n-6), 18:3(n-3), 20:4(n-6), 20:5(n-3) (eicosapentaenoic acid, EPA) and 22:6(n-3) (docosahexaenoic acid, DHA). Looking at the predominant FA, there appears to be a higher similarity between $P$. martia martia and $P$. serratus. The eggs of these species present similar levels of SFA, highly unsaturated (HUFA) and (n-3) FA but P. martia martia eggs have an extremely elevated MUFA and a low PUFA content. $P$. elegans has high levels of SFA, PUFA, HUFA and (n-3) FA. P. serratus and particularly P. martia martia eggs are characterised by a higher DHA:EPA ratio than $P$. elegans. The similarity between the FA profile of $P$. martia martia and $P$. serratus eggs may suggest that these 2 species are exposed to more comparable environmental conditions than $P$. elegans. As for the utilisation of FA classes during embryonic development, all species showed the same trend-MUFA were found to be the major energetic fuel during embryonic development while SFA and HUFA seemed to be conserved. A steady decrease in total lipids, particularly tri- (TAG) and diacylglycerol (DAG), and FA contents was noted in the 3 species. The utilisation of these lipid classes during the incubation period was comparatively low in P. martia martia and P. elegans in relation to $P$. serratus eggs. This may suggest a higher dependence of the newly hatched larvae of $P$. martia martia and $P$. elegans on their lipid reserves and has been interpreted as an adaptation to the early life history of these species, during which there might be a reduced availability of food.
\end{abstract}

KEY WORDS: Lipids · Fatty acid composition · Eggs $\cdot$ Caridea $\cdot$ Early life history $\cdot$ Environmental conditions Resale or republication not permitted without written consent of the publisher

\section{INTRODUCTION}

Lipids are considered the most important source of metabolic energy in decapod and other crustacean eggs. In marine demersal eggs of crustaceans and molluscs, 60 to $88 \%$ of the energy is drawn from fat oxidation during embryonic development (Pandian 1970a,b). The lipid content of decapod eggs may vary 
from 3.2 to $20.2 \%$ of the wet weight and considerable changes in these values occur during development. The fact that the amount of lipid reserves transferred from the female to the eggs may exceed $60 \%$ of that remaining in the female's body indicates that the lipid metabolism of the female is geared to the provision of egg lipid (Herring 1973).

Given that they are the main source of metabolic energy throughout embryonic development, the amount of lipids in the egg generally correlates with the size of the egg and with the time interval between spawning and hatching or larval first feeding (Herring 1973, Rainuzzo et al. 1997). In species with an abbreviated larval development, large energy reserves need to be provided for the developing embryo (Herring 1974). Phospholipids (PL) are of vital importance in maintaining the structural and physiological integrity of cellular membranes and, in crustaceans, glycerophospholipids are also crucial for the transport of substances via the hemolymph (Chapelle 1986).

The patterns of utilisation of specific lipid classes and fatty acids (FA) may be species-dependent and may reflect particular nutritional or environmental requirements. Relationships have been found between the ecology of the species and their lipid profile, with the egg FA profile reflecting the adult's diet and colder and/or deeper water species showing a higher degree of unsaturation in their FA profile (Narciso 1999). The crustaceans consist of a wide range of species adapted to a great variety of environmental conditions and there is evidence of adaptative mechanisms to changing environmental conditions in the metabolism of PL. It has long been recognised that the $(n-3)$ requirements of marine animals represent one of the adaptation mechanisms to changes in environmental factors, particularly temperature, and to a much lower degree, salinity. The requirement for high levels of polyunsaturated fatty acids (PUFA) from the (n-3) series, particularly 20:5(n-3) (EPA; eicosapentaenoic acid) and 22:6(n-3) (DHA; docosahexaenoic acid) is explained by the fact that the $(n-3)$ polyunsaturated structure permits greater flexibility of membranes and maintenance of the required physical properties at lower temperatures (Chapelle 1986).

Until now, few studies have examined the lipid composition of crustacean eggs (e.g. Dawson \& Barnes 1966, Pandian 1970a, Achitiv \& Barnes 1976, Amsler \& George 1984, Biesiot \& Perry 1995) and even fewer have looked at the FA depletion during embryonic development (Clarke et al. 1990, Kattner et al. 1994, Wehrtmann \& Graeve 1998, Wehrtmann \& Kattner 1998, Nates \& McKenney 2000, Narciso \& Morais 2001). A lot of research has been conducted to determine the essential FA requirements of crustacean species with aquaculture potential; a great deal of this research has focused on the quantitative and qualitative lipid requirements of commercially important species and relatively few studies have examined other crustacean species (D'Abramo \& Sheen 1993, Fox et al. 1994).

The present study examines changes in the egg lipid composition and FA profile of 3 temperate caridean species-Plesionika martia martia, Palaemon serratus and Palaemon elegans. These species were chosen because they occupy different ecological niches, although they have a similar reproductive strategy. The effect of the environmental conditions and early life history in the lipid embryonic metabolism of these species is analysed.

Plesionika martia martia A. Milne-Edwards, 1883 (Decapoda; Caridea; Pandalidae) is an epibenthic species, occurring between a depth of 190 and $1214 \mathrm{~m}$, being however more abundant between 200 and $700 \mathrm{~m}$. It may have a total length of up to $17 \mathrm{~cm}$ (Lagardère 1971). In the western Mediterranean, pandalid shrimps are active predators of macroplankton species and the diet of $P$. martia martia consists mainly of benthopelagic eucarid crustaceans (Cartes 1993). Ovigerous females are found between March and November, and present blue coloured eggs (Lagardère 1971, Calado \& Narciso 2002). It has a long larval development, presenting 11 zoeal stages (Kurian 1956, Barnich 1996).

Palaemon serratus (Pennant, 1777) (Decapoda; Caridea; Palaemonidae) is present in the infralitoral zone, in rocky substrates with algae and Zostera or in dark caves, up to a depth of $40 \mathrm{~m}$ (Udekem d'Acoz 1999). It has a total length of 7.5 to $11 \mathrm{~cm}$. P. serratus is an omnivorous species, feeding mainly on algae (Laminaria and Rhodophyceae) and small crustaceans, and also on a minor proportion of small molluscs and polychaetes (Lagardère 1971). Egg-bearing females may be generally found all-year round (Lagardère 1971, Calado \& Narciso 2002).

Palaemon elegans Rathke, 1837 (Decapoda; Caridea; Palaemonidae) is found in the intertidal zone, in sea grass beds or in rocky tidal pools, in the medium-litoral or even supra-litoral zone, occurring up to a depth of $5 \mathrm{~m}$. It is typically a marine species that can tolerate slightly brackish waters, although some populations have been found living in waters with a very low salinity, tolerating salinities lower than 16 ppm (Udekem d'Acoz 1999). It has a total length of 3 to $6.5 \mathrm{~cm}$. In the summer, $P$. elegans feeds mostly on filamentous algae and in the autumn they also start feeding on small crustaceans, particularly cyprids and Balanus sp. nauplii. Ovigerous females can be found from February to September (Lagardère 1971, Calado \& Narciso 2002). Even though $P$. serratus and $P$. elegans may present 7 to 9 zoeal stages, depending on temperature and salinity conditions, 9 larval stages have been recorded 
in the Portuguese coast (Fincham \& Williamson 1978, Fincham 1983, dos Santos 1999).

\section{MATERIALS AND METHODS}

Egg-bearing females of Plesionika martia martia and Palaemon serratus were collected from February to June 2001 after being landed in Cascais, Portugal, by commercial fishing vessels. Palaemon elegans ovigerous females were captured with dip-nets in the intertidal zone of Cape Raso, Cascais, Portugal. The egg mass was removed from the females and eggs were classified according to the following criteria (modified from Kattner et al. 1994): (1) Stage 1-uniform yolk and no embryonic development visible; (2) Stage 2eyes clearly visible with $1 / 2$ yolk consumed; and (3) Stage 3-almost no yolk present and embryo fully developed.

Thirty eggs were separated from each female (9 females per species, 3 per each embryonic stage) and length $(L)$ and width $(W)$ were measured (Table 1) under a stereo microscope (Olympus ${ }^{\circledR}$, Model SZ6045TR) with a calibrated micrometer eyepiece. The total length of each ovigerous female was measured with callipers rounded to the nearest $0.05 \mathrm{~mm}$; the average female size for all embryonic stages was 82,76 and 42 $\mathrm{mm}$ for Plesionika martia martia, Palaemon serratus and Palaemon elegans, respectively.

Egg volume $(V)$ was calculated using the formula for oblate spheroids $V=1 / 6\left(\pi W^{2} L\right.$ ) (Turner \& Lawrence 1979). To determine significant differences between the egg volume of the 3 species at different embryonic stages, a 2-way analysis of variance (MANOVA) was conducted, after the assumptions had been checked. Whenever significance was accepted at $\mathrm{p}<0.05$, the Tukey multiple comparison test was used (Zar 1996).
Egg samples from each species and embryonic stage of development were stored in liquid nitrogen for later lipid analysis. Given the small size of each egg batch, batches of eggs at the same stage of development were pooled for biochemical analysis. Water content was determined in duplicate by measuring the dry weight of the egg samples in a high precision Sartorius Supermicro $^{\circledR}$ balance $( \pm 0.2 \mu \mathrm{g})$, after freeze-drying in a Savant VP100 ${ }^{\circledR}$, and by relating it to the wet weight of the samples.

Total lipids were extracted using the Bligh \& Dyer (1959) method, with samples being ground in a Potter homogeniser with chloroform:methanol:water (2:2:1.8). Lipid classes were resolved by thin layer chromatography (TLC) in plates coated with $0.25 \mathrm{~mm}$ silica gel G (Merck) and developed with hexane:diethylether: acetic acid (65:35:1). The developed plates were sprayed with $10 \%$ phosphomolybdic acid in ethanol. Lipid class identification was made by comparison with standards (Sigma). Quantification was performed using a scanner and the software Quantity One (Version 2.4) from PDI. For the FA analysis, the lipid extracts were saponified and esterified according to Metcalfe \& Schmitz (1961) and the fatty acid methyl esters (FAME) were injected into a capillary column OmegaWax 320 WCOT (30 m fused silica, 0.32 internal diameter) installed in a Varian Star 3400CX gas-liquid chromatograph (GLC). Helium was used as carrier gas, at a flow rate of $1 \mathrm{ml} \mathrm{min}^{-1}$; oven temperature was $180^{\circ} \mathrm{C}$ for $7 \mathrm{~min}$ and then $200^{\circ} \mathrm{C}$ (with a temperature gradient of $4^{\circ} \mathrm{C} \mathrm{min}{ }^{-1}$ ) over a period of $71 \mathrm{~min}$. Both the split injector Varian 8200 CX (100:1) and the FID detector were set at $250^{\circ} \mathrm{C}$. GLC data acquisition and handling was done through a Varian integrator 4290 connected to the GLC. Peak quantification was carried out with a Star Chromatography workstation installed in an IBM PS/1. Peak identification was carried out

Table 1. Plesionika martia martia, Palaemon serratus and Palaemon elegans. Size of eggs (length and width in mm), total lipid (\% dry weight) and lipid class composition (\% of total lipids) at different stages of embryonic development. Values are means \pm SD ( $\mathrm{n}=90$ for egg size and $\mathrm{n}=3$ for lipid analysis). TAG: triacylglycerol, PL: phospholipids, DAG: diacylglycerol, MAG: monoacylglycerol, FFA: free fatty acids, FC: free cholesterol, CE: cholesterol ester

\begin{tabular}{|c|c|c|c|c|c|c|c|c|c|}
\hline & \multicolumn{3}{|c|}{ Plesionika martia martia } & \multicolumn{3}{|c|}{ Palaemon serratus } & \multicolumn{3}{|c|}{ Palaemon elegans } \\
\hline & 1 & 2 & 3 & 1 & 2 & 3 & 1 & 2 & 3 \\
\hline Egg length & $0.58 \pm 0.03$ & $0.65 \pm 0.03$ & $0.77 \pm 0.04$ & $0.66 \pm 0.02$ & $0.86 \pm 0.03$ & $1.15 \pm 0.07$ & $0.66 \pm 0.03$ & $0.76 \pm 0.02$ & $0.87 \pm 0.03$ \\
\hline Egg width & $0.43 \pm 0.03$ & $0.48 \pm 0.02$ & $0.55 \pm 0.04$ & $0.56 \pm 0.02$ & $0.63 \pm 0.02$ & $0.71 \pm 0.05$ & $0.52 \pm 0.02$ & $0.57 \pm 0.01$ & $0.60 \pm 0.02$ \\
\hline Total lipid & $17.5 \pm 0.9$ & $13.4 \pm 1.1$ & $7.2 \pm 1.3$ & $17.7 \pm 0.7$ & $14.8 \pm 1.6$ & $4.1 \pm 1.2$ & $19.5 \pm 1.8$ & $15.2 \pm 2.3$ & $8.1 \pm 0.8$ \\
\hline TAG & $46.7 \pm 6.9$ & $39.4 \pm 6.5$ & $3.9 \pm 1.6$ & $50.0 \pm 5.8$ & $39.7 \pm 8.0$ & $2.4 \pm 0.8$ & $42.0 \pm 6.8$ & $51.3 \pm 7.6$ & $6.8 \pm 3.4$ \\
\hline PL & $16.5 \pm 2.6$ & $16.2 \pm 5.1$ & $10.9 \pm 2.7$ & $7.8 \pm 0.8$ & $10.0 \pm 2.9$ & $15.8 \pm 5.3$ & $6.2 \pm 1.0$ & $7.0 \pm 0.7$ & $9.4 \pm 1.8$ \\
\hline DAG & $6.3 \pm 1.7$ & $6.4 \pm 2.2$ & $2.5 \pm 1.1$ & $5.1 \pm 0.3$ & $7.4 \pm 1.6$ & $1.6 \pm 0.7$ & $6.5 \pm 0.4$ & $5.6 \pm 1.1$ & $1.1 \pm 0.5$ \\
\hline MAG & $2.7 \pm 2.2$ & $3.2 \pm 2.9$ & $2.3 \pm 0.3$ & $2.0 \pm 0.5$ & $1.9 \pm 0.9$ & $3.4 \pm 1.3$ & $2.1 \pm 0.9$ & $1.6 \pm 0.1$ & $1.3 \pm 0.4$ \\
\hline FFA & $8.9 \pm 3.0$ & $11.7 \pm 0.8$ & $37.7 \pm 8.3$ & $20.7 \pm 2.3$ & $16.4 \pm 7.9$ & $48.9 \pm 5.3$ & $29.7 \pm 4.1$ & $20.9 \pm 9.1$ & $55.4 \pm 6.7$ \\
\hline $\mathrm{FC}$ & $8.7 \pm 2.2$ & $10.7 \pm 3.0$ & $10.8 \pm 3.2$ & $5.8 \pm 0.3$ & $10.7 \pm 2.7$ & $9.3 \pm 1.2$ & $5.3 \pm 0.8$ & $6.9 \pm 2.7$ & $9.6 \pm 2.0$ \\
\hline $\mathrm{CE}$ & $10.2 \pm 1.5$ & $12.5 \pm 1.6$ & $31.9 \pm 0.7$ & $8.7 \pm 5.6$ & $9.5 \pm 1.8$ & $18.6 \pm 5.7$ & $8.3 \pm 1.6$ & $6.8 \pm 0.9$ & $16.5 \pm 3.4$ \\
\hline
\end{tabular}




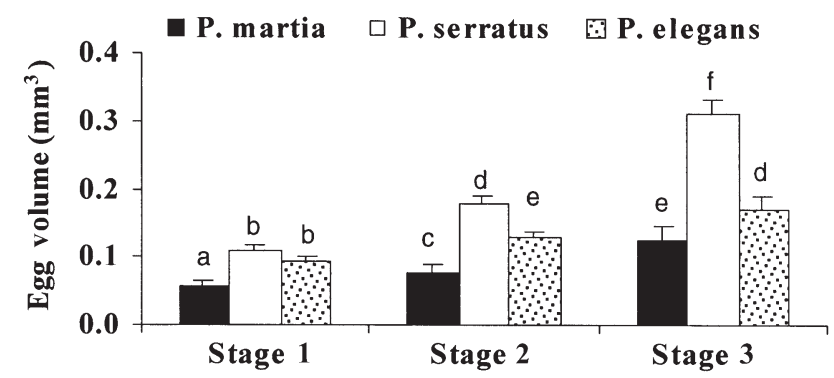

Fig. 1. Plesionika martia martia, Palaemon serratus and Palaemon elegans. Volume $\left(\mathrm{mm}^{3}\right)$ of eggs at different stages of embryonic development ( $\mathrm{n}=90$ for each species). Different letters represent statistically significant differences $(\mathrm{p}<0.0001)$

using as reference well-characterised cod liver oil chromatograms. Triplicate samples were analysed.

\section{RESULTS}

The changes in egg volume with developmental stage can be seen in Fig. 1. The results showed a significant increase in egg volume during embryonic development in the 3 analysed species ( $p<0.0001$ ). Significant differences were also found between the 3 species in each embryonic stage $(p<0.0001)$, with the exception of the 2 Palaemon species in Stage 1 $(p \geq 0.05)$. At the start of embryonic development, Palaemon serratus had the largest eggs $(0.11 \pm 0.009$ $\left.\mathrm{mm}^{3}\right)$, followed by Palaemon elegans $(0.09 \pm 0.007$ $\mathrm{mm}^{3}$ ), while Plesionika martia martia presented the eggs with the smallest volume $\left(0.06 \pm 0.008 \mathrm{~mm}^{3}\right)$. During embryogenesis, there was a much greater volume increment in $P$. serratus eggs $(188 \%)$ than in $P$. elegans or $P$. martia martia (79 and $121 \%$, respectively). Hence, just before hatching, $P$. serratus eggs had a significantly higher volume $\left(0.31 \pm 0.05 \mathrm{~mm}^{3}\right)$, followed by $P$. elegans $\left(0.17 \pm 0.01 \mathrm{~mm}^{3}\right)$ and $P$. martia martia $\left(0.12 \pm 0.02 \mathrm{~mm}^{3}\right)$.

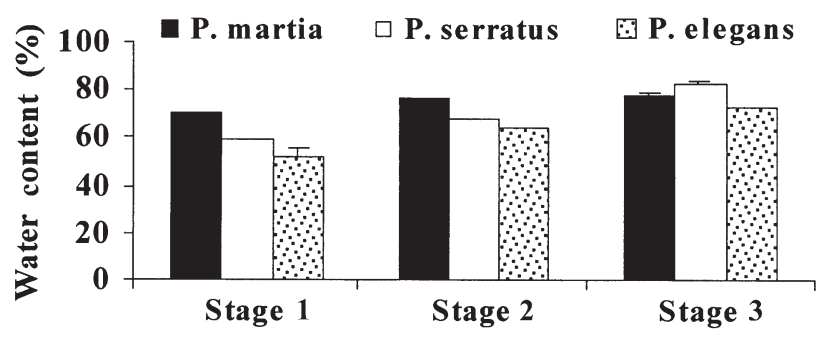

Fig. 2. Plesionika martia martia, Palaemon serratus and Palaemon elegans. Water content (\% of wet weight) of eggs at different stages of embryonic development. Values are means \pm SD (for each embryonic stage per species $n=2$ )
A progressive increase in the water content of the eggs was observed during embryonic development (Fig. 2). From the start of embryonic development to close to hatching, there was an increment from $70.2 \pm$ 0.3 to $77.2 \pm 1.5 \%$ in Plesionika martia martia, $59 \pm 0.1$ to $83.1 \pm 0.3 \%$ in Palaemon serratus and $52.2 \pm 3.9$ to $72.9 \pm 0.1 \%$ in Palaemon elegans eggs.

The lipid content of Plesionika martia martia, Palaemon serratus and Palaemon elegans eggs decreased considerably during embryonic development (Table 1), mainly between Stages 2 and 3. However, a higher lipid consumption was obtained in P. serratus $(76.3 \%)$ in comparison to the other species ( $P$. martia martia, $58.8 \% ;$ P. elegans, 58.4\%). The major lipid class in the early developmental stages of the 3 species analysed was triacylglycerol (TAG) $(46.7,50.0$ and $42.0 \%$ in $P$. martia martia, $P$. serratus and $P$. elegans, respectively). The second most abundant classes were PL in P. martia martia $(16.5 \%)$ and free fatty acids (FFA) in $P$. serratus and P. elegans (20.7 and $29.7 \%$, respectively). A substantial decrease in the TAG and diacylglycerol (DAG) percentage was observed during development in the 3 species and it was also more pronounced from Stage 2 to 3 . Concomitantly, an increase in the relative proportion of FFA and cholesterol esters (CE) was verified. Monoacylglycerols (MAG) presented an indistinct trend of variation during the development of the 3 species. Contrary to the PL percentages in $P$. serratus and $P$. elegans eggs, a decrease in the polar lipids was observed during embryonic development in P. martia martia.

The FA analysis of Plesionika martia martia, Palaemon serratus and Palaemon elegans eggs (Table 2) revealed that the quantitatively most important FA are the saturates (SFA) 14:0, 16:0, 17:0 and 18:0, the monounsaturates (MUFA) 16:1(n-7), 18:1(n-9) and 18:1(n-7) and the PUFA 18:2(n-6), 18:3(n-3), 20:4(n-6) (ARA; arachidonic acid), 20:5(n-3) (EPA) and 22:6(n-3) (DHA). In spite of the similarity in terms of the most important FA in the different species, there are slight differences in the ordering of these FA by decreasing magnitude. Thus, in $P$. martia martia eggs, the most important fatty acids are 18:1(n-9), followed by 16:0, DHA, EPA and 16:1(n-7). P. serratus eggs are characterised by high levels of 18:1(n-9), followed by 16:0, 18:2(n-6), EPA, DHA and $16: 1(\mathrm{n}-7)$. As for the $P$. elegans eggs, the qualitatively most important FA are, by decreasing order of magnitude, EPA, 16:0, 18:1(n-9), 16:1(n-7), 18:1(n-7) and DHA. Furthermore, some FA appear in relatively high amounts in some species and not in others; this is the case of 20:1(n-9) in P. martia martia eggs, 18:2(n-6) and 20:2(n-6) in P. serratus eggs, and 22:5(n-3) in P. elegans eggs.

Looking at the egg composition in terms of the total FA classes, some interesting results were obtained. 
Table 2. Plesionika martia martia, Palaemon serratus and Palaemon elegans. Fatty acid composition $\left(\mu g \mathrm{mg}^{-1} \mathrm{DW}\right)$ of eggs at different stages of embryonic development. Values are means of triplicate samples \pm SD. MUFA: monounsaturated fatty acids, PUFA: polyunsaturated fatty acids, HUFA: highly unsaturated fatty acids, DHA: docosahexaenoic acid, EPA: eicosa-pentaenoic acid, FAME: fatty acid methyl esters

\begin{tabular}{|c|c|c|c|c|c|c|c|c|c|}
\hline \multirow{2}{*}{$\begin{array}{l}\text { Fatty } \\
\text { acid }\end{array}$} & \multicolumn{3}{|c|}{ Plesionika martia martia } & \multicolumn{3}{|c|}{ Palaemon serratus } & \multicolumn{3}{|c|}{ Palaemon elegans } \\
\hline & 1 & 2 & 3 & 1 & 2 & 3 & 1 & 2 & 3 \\
\hline $14: 0$ & $3.9 \pm 0.0$ & $3.8 \pm 0.1$ & $3.5 \pm 0.3$ & $2.6 \pm 0.3$ & $3.2 \pm 0.1$ & $1.2 \pm 0.1$ & $5.7 \pm 0.2$ & $5.5 \pm 1.6$ & $4.4 \pm 0.3$ \\
\hline $15: 0$ & $1.3 \pm 0.0$ & $1.0 \pm 0.0$ & $0.7 \pm 0.0$ & $1.3 \pm 0.1$ & $1.3 \pm 0.1$ & $0.5 \pm 0.0$ & $0.9 \pm 0.1$ & $1.0 \pm 0.2$ & $0.8 \pm 0.0$ \\
\hline $16: 0$ & $29.6 \pm 0.3$ & $25.6 \pm 0.5$ & $24.7 \pm 1.3$ & $26.6 \pm 0.1$ & $26.8 \pm 0.8$ & $12.4 \pm 0.2$ & $30.6 \pm 2.2$ & $29.3 \pm 0.4$ & $22.7 \pm 2.9$ \\
\hline $17: 0$ & $2.4 \pm 0.1$ & $2.3 \pm 0.1$ & $1.7 \pm 0.1$ & $3.2 \pm 0.0$ & $2.5 \pm 0.3$ & $1.1 \pm 0.1$ & $2.6 \pm 0.2$ & $3.0 \pm 0.6$ & $1.8 \pm 0.0$ \\
\hline $18: 0$ & $6.0 \pm 0.1$ & $5.7 \pm 0.1$ & $5.8 \pm 0.2$ & $9.2 \pm 0.3$ & $7.7 \pm 0.3$ & $4.3 \pm 0.2$ & $10.9 \pm 0.0$ & $10.2 \pm 0.4$ & $7.5 \pm 0.7$ \\
\hline $20: 0$ & $0.5 \pm 0.1$ & $0.5 \pm 0.1$ & $0.5 \pm 0.1$ & $0.4 \pm 0.0$ & $0.4 \pm 0.1$ & $0.4 \pm 0.2$ & $0.5 \pm 0.1$ & $0.6 \pm 0.0$ & $0.4 \pm 0.0$ \\
\hline $22: 0$ & $0.3 \pm 0.0$ & $0.2 \pm 0.0$ & $0.4 \pm 0.1$ & $0.4 \pm 0.0$ & $0.4 \pm 0.0$ & $1.5 \pm 2.1$ & $0.3 \pm 0.0$ & $0.4 \pm 0.0$ & $0.4 \pm 0.0$ \\
\hline$\sum$ Saturated & $44.0 \pm 0.4$ & $39.1 \pm 0.6$ & $37.3 \pm 2.1$ & $43.7 \pm 0.0$ & $42.4 \pm 1.0$ & $21.6 \pm 2.0$ & $51.7 \pm 2.5$ & $50.1 \pm 0.1$ & $38.0 \pm 3.9$ \\
\hline Iso $15: 0$ & $0.3 \pm 0.0$ & $0.3 \pm 0.1$ & $0.2 \pm 0.0$ & $0.5 \pm 0.1$ & $0.7 \pm 0.1$ & $0.3 \pm 0.1$ & $0.2 \pm 0.1$ & $0.2 \pm 0.1$ & $0.1 \pm 0.0$ \\
\hline Iso $16: 0$ & $0.3 \pm 0.0$ & $0.3 \pm 0.0$ & $0.4 \pm 0.1$ & $0.4 \pm 0.0$ & $0.4 \pm 0.0$ & $0.2 \pm 0.0$ & $0.2 \pm 0.0$ & $0.3 \pm 0.0$ & $0.2 \pm 0.0$ \\
\hline Iso $17: 0$ & $0.9 \pm 0.0$ & $0.8 \pm 0.0$ & $0.5 \pm 0.0$ & $1.7 \pm 0.1$ & $1.5 \pm 0.1$ & $0.5 \pm 0.0$ & $1.0 \pm 0.2$ & $1.0 \pm 0.1$ & $0.7 \pm 0.0$ \\
\hline Anteiso 17:0 & $0.3 \pm 0.0$ & $0.3 \pm 0.0$ & $0.1 \pm 0.0$ & $1.0 \pm 0.1$ & $1.0 \pm 0.0$ & $0.4 \pm 0.1$ & $0.3 \pm 0.1$ & $0.4 \pm 0.0$ & $0.3 \pm 0.1$ \\
\hline$\sum$ Branched & $1.9 \pm 0.0$ & $1.7 \pm 0.0$ & $1.2 \pm 0.1$ & $3.8 \pm 0.3$ & $3.6 \pm 0.1$ & $1.4 \pm 0.1$ & $1.8 \pm 0.5$ & $2.0 \pm 0.3$ & $1.3 \pm 0.1$ \\
\hline $16: 1(n-7)$ & $17.8 \pm 0.4$ & $15.4 \pm 0.4$ & $12.2 \pm 0.9$ & $12.0 \pm 0.5$ & $12.2 \pm 0.4$ & $3.7 \pm 0.1$ & $19.4 \pm 1.3$ & $15.3 \pm 3.7$ & $12.3 \pm 1.1$ \\
\hline 18:1(n-9) & $45.1 \pm 0.5$ & $35.1 \pm 0.8$ & $32.4 \pm 1.9$ & $43.3 \pm 0.9$ & $49.5 \pm 1.6$ & $13.0 \pm 0.6$ & $20.0 \pm 3.4$ & $18.4 \pm 2.0$ & $13.0 \pm 0.9$ \\
\hline $18: 1(n-7)$ & $10.8 \pm 0.4$ & $10.9 \pm 0.1$ & $8.5 \pm 0.4$ & $9.0 \pm 1.0$ & $8.8 \pm 0.3$ & $4.5 \pm 0.1$ & $15.5 \pm 0.2$ & $13.9 \pm 1.8$ & $11.7 \pm 1.5$ \\
\hline 18:1(n-5) & $0.3 \pm 0.0$ & $0.4 \pm 0.0$ & $0.2 \pm 0.0$ & $0.3 \pm 0.0$ & $0.3 \pm 0.0$ & $0.0 \pm 0.0$ & $0.3 \pm 0.0$ & $0.3 \pm 0.0$ & $0.2 \pm 0.0$ \\
\hline 20:1(n-9) & $3.4 \pm 0.1$ & $3.3 \pm 0.1$ & $3.0 \pm 0.2$ & $1.1 \pm 0.0$ & $1.1 \pm 0.0$ & $0.2 \pm 0.2$ & $0.7 \pm 0.2$ & $1.2 \pm 0.5$ & $0.5 \pm 0.1$ \\
\hline $20: 1(n-7)$ & $0.6 \pm 0.1$ & $0.9 \pm 0.1$ & $0.3 \pm 0.0$ & $0.6 \pm 0.1$ & $0.6 \pm 0.0$ & $0.0 \pm 0.0$ & $1.1 \pm 0.3$ & $1.0 \pm 0.3$ & $0.7 \pm 0.1$ \\
\hline $20: 1(n-5)$ & $0.1 \pm 0.0$ & $0.6 \pm 0.4$ & $0.0 \pm 0.0$ & $0.4 \pm 0.3$ & $0.2 \pm 0.0$ & $0.0 \pm 0.0$ & $0.2 \pm 0.0$ & $0.2 \pm 0.0$ & $0.1 \pm 0.0$ \\
\hline $22: 1(\mathrm{n}-11)$ & $1.0 \pm 0.0$ & $0.4 \pm 0.0$ & $1.4 \pm 0.1$ & $0.2 \pm 0.0$ & $0.1 \pm 0.0$ & $0.0 \pm 0.0$ & $0.1 \pm 0.0$ & $0.1 \pm 0.0$ & $0.1 \pm 0.0$ \\
\hline $22: 1(n-9)$ & $0.4 \pm 0.0$ & $0.4 \pm 0.0$ & $0.4 \pm 0.0$ & $0.1 \pm 0.0$ & $0.1 \pm 0.0$ & $0.0 \pm 0.0$ & $0.0 \pm 0.0$ & $0.0 \pm 0.0$ & $0.0 \pm 0.0$ \\
\hline $24: 1(n-9)$ & $0.4 \pm 0.0$ & $0.4 \pm 0.0$ & $0.3 \pm 0.0$ & $0.1 \pm 0.0$ & $0.1 \pm 0.0$ & $0.0 \pm 0.0$ & $0.1 \pm 0.0$ & $0.1 \pm 0.0$ & $0.0 \pm 0.0$ \\
\hline$\sum$ MUFA & $80.7 \pm 1.3$ & $68.4 \pm 0.4$ & $59.2 \pm 3.6$ & $67.6 \pm 1.2$ & $73.1 \pm 2.4$ & $21.4 \pm 1.0$ & $57.9 \pm 4.8$ & $50.4 \pm 2.8$ & $38.8 \pm 3.6$ \\
\hline $16: 2(n-4)$ & $1.1 \pm 0.0$ & $0.9 \pm 0.0$ & $0.8 \pm 0.0$ & $1.8 \pm 0.0$ & $1.5 \pm 0.1$ & $0.9 \pm 0.1$ & $2.6 \pm 0.1$ & $2.3 \pm 0.4$ & $1.8 \pm 0.3$ \\
\hline $18: 2(n-6)$ & $4.9 \pm 0.1$ & $2.5 \pm 0.1$ & $2.9 \pm 0.3$ & $26.9 \pm 2.6$ & $25.3 \pm 0.9$ & $10.0 \pm 0.5$ & $6.1 \pm 2.0$ & $6.6 \pm 2.6$ & $4.4 \pm 0.8$ \\
\hline 18:3(n-3) & $2.3 \pm 0.1$ & $1.5 \pm 0.2$ & $1.0 \pm 0.1$ & $2.8 \pm 0.1$ & $2.0 \pm 0.1$ & $0.5 \pm 0.1$ & $4.1 \pm 1.1$ & $5.7 \pm 2.6$ & $3.0 \pm 1.1$ \\
\hline $18: 4(n-3)$ & $0.8 \pm 0.0$ & $0.6 \pm 0.1$ & $0.4 \pm 0.0$ & $0.8 \pm 0.1$ & $0.5 \pm 0.2$ & $0.1 \pm 0.1$ & $3.0 \pm 0.1$ & $2.9 \pm 0.1$ & $1.8 \pm 0.5$ \\
\hline $20: 2(n-6)$ & $0.9 \pm 0.2$ & $2.3 \pm 1.6$ & $0.6 \pm 0.0$ & $4.7 \pm 0.1$ & $4.4 \pm 0.1$ & $1.4 \pm 0.0$ & $1.1 \pm 0.1$ & $1.0 \pm 0.2$ & $0.9 \pm 0.0$ \\
\hline $20: 3(n-6)$ & $0.2 \pm 0.1$ & $1.3 \pm 0.5$ & $0.2 \pm 0.1$ & $0.7 \pm 0.1$ & $0.6 \pm 0.0$ & $0.0 \pm 0.0$ & $0.7 \pm 0.0$ & $0.6 \pm 0.0$ & $0.5 \pm 0.1$ \\
\hline $20: 4(n-6)$ & $4.7 \pm 0.4$ & $5.0 \pm 0.4$ & $3.1 \pm 0.1$ & $7.0 \pm 0.0$ & $4.6 \pm 0.2$ & $2.8 \pm 0.7$ & $5.3 \pm 0.4$ & $5.4 \pm 0.4$ & $3.8 \pm 0.4$ \\
\hline 20:3(n-3) & $0.6 \pm 0.3$ & $2.4 \pm 1.1$ & $0.4 \pm 0.0$ & $0.7 \pm 0.2$ & $0.7 \pm 0.0$ & $2.3 \pm 0.1$ & $0.9 \pm 0.1$ & $1.3 \pm 0.4$ & $1.1 \pm 0.7$ \\
\hline $20: 4(n-3)$ & $1.1 \pm 0.4$ & $1.7 \pm 0.2$ & $0.7 \pm 0.0$ & $0.5 \pm 0.2$ & $0.4 \pm 0.0$ & $0.0 \pm 0.0$ & $1.1 \pm 0.1$ & $1.9 \pm 0.7$ & $1.2 \pm 0.8$ \\
\hline $20: 5(n-3)$ & $22.6 \pm 4.1$ & $23.5 \pm 0.5$ & $18.9 \pm 1.1$ & $25.7 \pm 1.7$ & $23.8 \pm 0.7$ & $17.9 \pm 2.3$ & $54.6 \pm 1.0$ & $43.0 \pm 9.3$ & $38.8 \pm 6.8$ \\
\hline $21: 5(n-3)$ & $0.4 \pm 0.0$ & $0.4 \pm 0.0$ & $0.3 \pm 0.0$ & $0.6 \pm 0.0$ & $0.4 \pm 0.0$ & $0.0 \pm 0.0$ & $1.2 \pm 0.0$ & $0.7 \pm 0.4$ & $0.7 \pm 0.1$ \\
\hline $22: 4(n-6)$ & $0.7 \pm 0.0$ & $0.6 \pm 0.0$ & $0.5 \pm 0.0$ & $0.8 \pm 0.0$ & $0.6 \pm 0.0$ & $0.1 \pm 0.1$ & $0.5 \pm 0.0$ & $0.4 \pm 0.0$ & $0.3 \pm 0.0$ \\
\hline $22: 5(n-6)$ & $0.1 \pm 0.0$ & $0.0 \pm 0.0$ & $0.0 \pm 0.0$ & $0.0 \pm 0.0$ & $0.0 \pm 0.0$ & $0.0 \pm 0.0$ & $0.0 \pm 0.0$ & $0.0 \pm 0.0$ & $0.0 \pm 0.0$ \\
\hline $22: 5(n-3)$ & $1.4 \pm 0.0$ & $1.5 \pm 0.0$ & $1.1 \pm 0.1$ & $2.1 \pm 0.2$ & $1.8 \pm 0.0$ & $0.2 \pm 0.2$ & $3.5 \pm 0.7$ & $3.0 \pm 0.6$ & $2.0 \pm 0.1$ \\
\hline $22: 6(n-3)$ & $24.5 \pm 0.5$ & $20.2 \pm 0.6$ & $19.2 \pm 1.1$ & $15.6 \pm 0.3$ & $17.3 \pm 0.4$ & $7.5 \pm 0.5$ & $11.8 \pm 0.8$ & $11.1 \pm 1.5$ & $9.1 \pm 0.2$ \\
\hline$\sum$ PUFA & $65.1 \pm 5.9$ & $63.4 \pm 2.2$ & $49.1 \pm 3.0$ & $88.9 \pm 0.2$ & $82.4 \pm 2.6$ & $42.7 \pm 0.9$ & $93.9 \pm 2.2$ & $83.6 \pm 4.0$ & $67.6 \pm 11.3$ \\
\hline$\sum$ HUFA & $57.2 \pm 5.9$ & $58.9 \pm 2.5$ & $44.9 \pm 2.7$ & $58.4 \pm 2.7$ & $54.6 \pm 1.4$ & $32.1 \pm 1.7$ & $80.8 \pm 1.0$ & $68.4 \pm 9.0$ & $58.3 \pm 8.9$ \\
\hline$\sum$ Unsaturated & $145.8 \pm 7.1$ & $131.8 \pm 1.7$ & $108.3 \pm 6.5$ & $156.4 \pm 1.4$ & $155.5 \pm 5.0$ & $64.2 \pm 0.0$ & $151.7 \pm 7.0$ & $134.0 \pm 6.8$ & $106.3 \pm 9.9$ \\
\hline$\sum(\mathrm{n}-3)$ & $53.6 \pm 5.3$ & $51.9 \pm 0.1$ & $41.9 \pm 2.4$ & $48.7 \pm 2.6$ & $46.9 \pm 1.4$ & $28.5 \pm 2.3$ & $80.1 \pm 0.6$ & $69.6 \pm 7.0$ & $57.7 \pm 9.8$ \\
\hline $\bar{\Sigma}(\mathrm{n}-6)$ & $11.5 \pm 0.6$ & $11.6 \pm 2.3$ & $7.3 \pm 0.5$ & $40.1 \pm 2.4$ & $35.5 \pm 1.1$ & $14.3 \pm 1.4$ & $13.7 \pm 1.6$ & $14.0 \pm 3.0$ & $9.9 \pm 1.4$ \\
\hline$(n-3) /(n-6)$ & $4.6 \pm 0.2$ & $4.6 \pm 0.9$ & $5.8 \pm 0.1$ & $1.2 \pm 0.1$ & $1.3 \pm 0.0$ & $2.0 \pm 0.4$ & $5.9 \pm 0.6$ & $5.2 \pm 1.6$ & $5.8 \pm 0.2$ \\
\hline DHA:EPA & $1.1 \pm 0.2$ & $0.9 \pm 0.0$ & $1.0 \pm 0.0$ & $0.6 \pm 0.0$ & $0.7 \pm 0.0$ & $0.4 \pm 0.0$ & $0.2 \pm 0.0$ & $0.3 \pm 0.0$ & $0.2 \pm 0.1$ \\
\hline$\sum$ Total FAME & $191.7 \pm 7.6$ & $172.6 \pm 1.2$ & $146.8 \pm 8.7$ & $203.9 \pm 1.7$ & $201.5 \pm 6.0$ & $87.2 \pm 2.1$ & $205.2 \pm 9.9$ & $186.1 \pm 6.9$ & $145.7 \pm 9.9$ \\
\hline
\end{tabular}


Plesionika martia martia and Palaemon serratus have a higher resemblance with respect to the total SFA, (n-3) FA and highly unsaturated fatty acids (HUFA) content of their eggs. Nevertheless, P. martia martia eggs stand out by having elevated MUFA and reduced PUFA contents. Palaemon elegans eggs have high levels of both SFA, PUFA, HUFA and (n-3) FA, while P. serratus eggs show intermediate levels of most FA classes, with the exception of (n-6) FA, which they have in large amounts due to the abundance of 18:2(n-6).

When analysing the changes in the egg FA profile during embryonic development, a steady decrease in the total FA is observed. Again, as observed with total lipids, the most pronounced reduction occurred from Stage 2 to 3 . The comparison of the total FA composition of the eggs in Stage 1 reveals that there is a similar level in the 3 species, with Plesionika martia martia presenting a just slightly lower FA content. Nevertheless, looking at the consumption rate during embryonic development, a much higher FA depletion was noted in Palaemon serratus eggs (57.3\%), in comparison with Palaemon elegans $(29.0 \%)$ and P. martia martia $(23.4 \%)$.

Looking at the utilisation of FA during embryonic development (Fig. 3), it can be noted that the unsaturated fatty acids (UFA) are used up at a higher rate than SFA; within the UFA, MUFA are consumed more than PUFA. As for the consumption of (n-3) and (n-6) FA, a preferential use of (n-6) FA during development was detected in Plesionika martia martia and Palae- mon serratus eggs, whereas both series were utilised at the same rate in Palaemon elegans eggs. As a result, an increase in the (n-3):(n-6) ratio was observed in $P$. martia martia and $P$. serratus during embryonic development, being this ratio kept constant in $P$. elegans eggs. In terms of the utilisation of individual FA, the results differ in the 3 species. In $P$. martia martia eggs, there was a preferential consumption (by order of decreasing magnitude) of 18:3(n-3), 18:2(n-6), ARA and $16: 1(\mathrm{n}-7) ; P$. serratus eggs showed a faster depletion of 18:3(n-3), 20:1(n-9), 18:1(n-9) and 16:1(n-7), whereas the results point to a higher reduction in 16:1(n-7), 18:1(n-9), 20:1(n-9) and 18:0 in P. elegans eggs.

In all 3 species, there was a catabolism of both DHA and EPA during embryonic development. In Plesionika martia martia and Palaemon serratus eggs, DHA was slightly more depleted than EPA, while the inverse was observed in Palaemon elegans. However, the differences in the consumption rate of these 2 essential FA were small and the DHA:EPA ratio was kept relatively constant during the embryonic development of these shrimp species.

When the FA analysis results are expressed in terms of percentage of total FA (Table 3), some interesting observations can be made. Again, as expected, the results point to a higher similarity between Plesionika martia martia and Palaemon serratus eggs. One result that stands out is the stability that is maintained in the proportion of the different FA during the embryonic
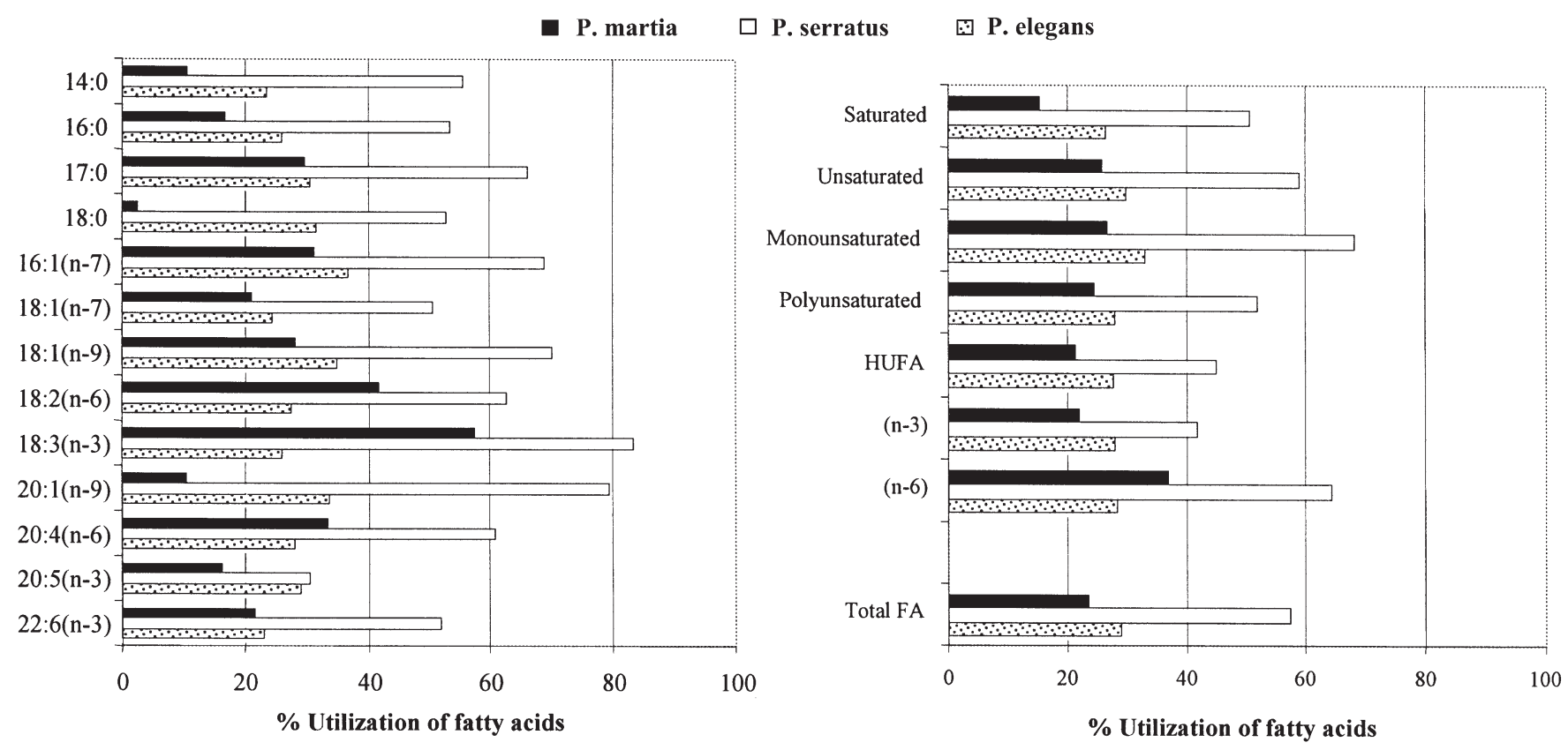

Fig. 3. Plesionika martia martia, Palaemon serratus and Palaemon elegans. Percentage of utilisation of selected fatty acids (FA), fatty acid classes and total fatty acid from the early to the later stage of embryonic development. HUFA: highly unsatuated fatty acids 
Table 3. Plesionika martia martia, Palaemon serratus and Palaemon elegans. Relative fatty acid composition (\% total lipids) of eggs at different stages of embryonic development (only the quantitatively most important fatty acids are represented). MUFA: monounsaturated fatty acids, PUFA: polyunsaturated fatty acids, HUFA: highly unsatuated fatty acids

\begin{tabular}{|c|c|c|c|c|c|c|c|c|c|}
\hline \multirow{2}{*}{$\begin{array}{l}\text { Fatty } \\
\text { acid }\end{array}$} & \multicolumn{3}{|c|}{ Plesionika martia martia } & \multicolumn{3}{|c|}{ Palaemon serratus } & \multicolumn{3}{|c|}{ Palaemon elegans } \\
\hline & 1 & 2 & 3 & 1 & 2 & 3 & 1 & 2 & 3 \\
\hline $14: 0$ & 2.04 & 2.18 & 2.38 & 1.29 & 1.60 & 1.34 & 2.80 & 2.96 & 3.02 \\
\hline $16: 0$ & 15.43 & 14.84 & 16.79 & 13.03 & 13.30 & 14.19 & 14.91 & 15.77 & 15.55 \\
\hline $17: 0$ & 1.26 & 1.31 & 1.16 & 1.59 & 1.23 & 1.26 & 1.28 & 1.59 & 1.25 \\
\hline $18: 0$ & 3.10 & 3.28 & 3.95 & 4.50 & 3.80 & 4.95 & 5.31 & 5.49 & 5.13 \\
\hline$\sum$ Saturated & 22.96 & 22.63 & 25.40 & 21.42 & 21.04 & 24.78 & 25.18 & 26.92 & 26.10 \\
\hline $16: 1(n-7)$ & 9.26 & 8.93 & 8.33 & 5.90 & 6.05 & 4.28 & 9.44 & 8.20 & 8.41 \\
\hline $18: 1(n-9)$ & 23.51 & 20.32 & 22.07 & 21.26 & 24.56 & 14.91 & 9.73 & 9.87 & 8.93 \\
\hline $18: 1(n-7)$ & 5.63 & 6.33 & 5.81 & 4.43 & 4.37 & 5.10 & 7.55 & 7.49 & 8.03 \\
\hline 20:1(n-9) & 1.77 & 1.91 & 2.06 & 0.54 & 0.55 & 0.26 & 0.34 & 0.63 & 0.32 \\
\hline$\sum$ MUFA & 42.12 & 39.60 & 40.31 & 33.14 & 36.30 & 24.56 & 28.19 & 27.11 & 26.60 \\
\hline $18: 2(n-6)$ & 2.55 & 1.42 & 1.94 & 13.18 & 12.56 & 11.50 & 2.96 & 3.54 & 3.03 \\
\hline $18: 3(n-3)$ & 1.19 & 0.86 & 0.66 & 1.37 & 0.98 & 0.53 & 1.97 & 3.08 & 2.06 \\
\hline $20: 4(n-6)$ & 2.45 & 2.90 & 2.13 & 3.46 & 2.29 & 3.16 & 2.60 & 2.89 & 2.63 \\
\hline $20: 5(n-3)$ & 11.79 & 13.62 & 12.85 & 12.60 & 11.81 & 20.49 & 26.62 & 23.11 & 26.61 \\
\hline $22: 6(n-3)$ & 12.78 & 11.72 & 13.09 & 7.66 & 8.58 & 8.64 & 5.75 & 5.96 & 6.24 \\
\hline$\sum$ Unsaturated & 76.08 & 76.35 & 73.77 & 76.72 & 77.18 & 73.58 & 73.94 & 72.02 & 72.98 \\
\hline$\sum$ PUFA & 33.96 & 36.75 & 33.46 & 43.58 & 40.89 & 49.01 & 45.75 & 44.91 & 46.38 \\
\hline$\sum$ HUFA & 29.81 & 34.12 & 30.61 & 28.66 & 27.09 & 36.82 & 39.36 & 36.74 & 40.02 \\
\hline$\sum(\mathrm{n}-3)$ & 27.95 & 30.04 & 28.51 & 23.91 & 23.29 & 32.66 & 39.05 & 37.41 & 39.62 \\
\hline$\sum(n-6)$ & 6.01 & 6.71 & 4.95 & 19.68 & 17.60 & 16.35 & 6.70 & 7.50 & 6.76 \\
\hline
\end{tabular}

development of Palaemon elegans eggs. In all species, there was a decrease in the percentages of both MUFA and UFA, mainly as a consequence of the decline on the proportions of 16:1(n-7) and 18:1(n-9). Total (n-6) FA, as well as 18:2(n-6) and 18:3(n-3), decrease their percentage during the embryonic development of $P$. martia martia and $P$. serratus but remain constant in $P$. elegans eggs. On the other hand, the SFA percentage (mainly 14:0 and 16:0) increases in all species. The proportions of PUFA and HUFA either increase or remain stable; DHA increases in all species, while EPA increases in P. martia martia and particularly in $P$. serratus eggs but remains constant in P. elegans.

\section{DISCUSSION}

Egg size has been correlated with lipid content, maternal investment and with the type of larval development in caridean decapods (Herring 1973, Clarke 1993, Wehrtmann \& Graeve 1998). Normally, small eggs hatch in small larvae that pass through a large number of developmental stages, whereas large eggs hatch into a more advanced stage, with fewer larval stages, or directly into post-larvae (Herring 1974). However, most crustacean larvae hatch with little or no yolk reserves, have extremely high energetic and nutritional demands, and are therefore dependent on the availability of a suitable diet for growth and metamorphosis (McConaugha 1985). This is the case for the species analysed in the present study.

In general, deeper water species tend to produce a smaller number of large eggs, with a longer development period and more lipid reserves, as a way to offset the decrease in the probability of larval mortality with depth (King \& Butler 1985, Mauchline 1988, Jaeckle 1995). In contrast, littoral species whose larvae are released and dispersed from the coastal nearshore zone have higher larval/post-larval mortality due to predation and drift; in this case, small eggs are usually produced as an adaptation to allow for larger brood sizes and greater egg production in shallow water species (Pollock \& Melville-Smith 1993). In spite of the much higher depth at which Plesionika martia martia is found, the eggs of this species are smaller than the eggs of Palaemon serratus and Palaemon elegans. This 
is probably a consequence of the type of larval development, which is similar in the 3 studied species, with several larval stages and a relatively long period of larval development.

An increase in egg volume during the incubation period has been reported to be typical in several crustacean species (Clarke et al. 1990, Biesiot \& Perry 1995, Lardies \& Wehrtmann 1996, Wehrtmann \& Graeve 1998, Wehrtmann \& Kattner 1998). In the present study, a significant increase in egg volume was also noted during embryogenesis $(121,188$ and $79 \%$ in Plesionika martia martia, Palaemon serratus and Palaemon elegans, respectively). This increase is within the range described for other decapod species and is generally associated with water uptake and a subsequent wet weight increase, accompanied by a decrease in dry weight (Pandian 1970a, Biesiot \& Perry 1995, Lardies \& Wehrtmann 1996, Wehrtmann \& Kattner 1998). Nevertheless, it is not completely clear whether the increase in water content is caused entirely by the absorption of water. Given that water is a by-product of respiration, the retention of metabolic water is also likely (Amsler \& George 1984).

In the present study, the increase in the egg water content of the 3 analysed species during embryonic development was comparable to other marine crustacean species (Pandian 1970a,b, Clarke et al. 1990, Petersen \& Anger 1997, Wehrtmann \& Graeve 1998). However, there appears to be a clear distinction between the different genera with Plesionika martia martia eggs having a higher water content at the earlier developmental stage than the 2 Palaemon species. In the latter species, a larger increase in water content is observed during embryonic development, with a relatively similar water content being measured in all 3 species just before hatching.

The lipid content of crustacean eggs has been typically found to decrease during development due to embryonic utilisation (Herring 1974, Wehrtmann \& Graeve 1998, Wehrtmann \& Kattner 1998). In the present study, a substantial decrease in the total lipid and FA content was also noted in the eggs of the 3 studied species. However, a higher percentage of lipid and FA utilisation was observed in Palaemon serratus eggs. These results suggest that both Plesionika martia martia and Palaemon elegans newly hatched larvae rely heavily on the endogenous lipid reserves, particularly for metabolic energetic purposes. An enhanced independence of the larvae on external energy sources has been interpreted as an adaptation to the early life history of the species (Wehrtmann \& Graeve 1998). P. serratus inhabits a less fluctuating environment (infralittoral) than $P$. elegans (intertidal) and P. martia martia (deep sea). P. elegans larvae hatch in habitats characterised by strong currents and wave action and, consequently, must be adapted to a broader range of environmental conditions than $P$. serratus, as was demonstrated by Berglund (1980) and Berglund \& Bengtsson (1981) in other intertidal and infralittoral Palaemon species. On the other hand, P. martia martia, like other deep-water pandalids, produce planktotrophic larvae that can migrate through the water column (Rothlisberg \& Pearcy 1977, King \& Buttler 1985). Consequently, these larvae are subjected to a great range of environmental factors during their vertical migration which may reduce their probability of survival (Mileikovsky 1971). Therefore, given the particular conditions to which newly hatched $P$. elegans and P. martia martia are submitted, a limited access to food immediately after hatching is likely. Nevertheless, in spite of this apparently similar strategy of $P$. martia martia and $P$. elegans, the egg FA profile of these 2 species is quite dissimilar, probably as a result of different diets and environmental conditions to which the females are submitted.

Egg lipids of the 3 investigated species also showed a clear trend of decreasing TAG and DAG during the early and late incubation period. In fact, neutral lipids, particularly TAG, are the major energy source and the predominant form of energy storage in the adult, egg and pre-feeding larva (Middleditch et al. 1979, Harrison 1990, Anger 1998). The utilisation of TAG during embryonic development implies a release of FA. The excess FFA can be diverted to growth at any point in larval development (Nates \& McKenney 2000), given that the bioconversion and incorporation of FFA into polar lipids is higher than into neutral lipids during embryogenesis (Dall et al. 1993).

Taking into account the predominant FA in the eggs, there appears to be a higher similarity between Plesionika martia martia and Palaemon serratus. The eggs of these 2 species are also characterised by presenting higher levels of DHA and a lower EPA composition than the eggs of Palaemon elegans, which present an extremely elevated EPA content. Consequently, $P$. martia martia and $P$. serratus eggs have higher DHA:EPA ratios (1.1 and 0.6 at the start of the embryonic development, respectively) than $P$. elegans (0.2). In fact, with increasing depth (i.e. increase in pressure and decrease in temperature), there appears to be an increase in the DHA:EPA ratio of the eggs, as a result of the rise in the DHA level and a reduction in the EPA content (Kattner et al. 1994).

In spite of the occurrence of species-specific patterns of FA utilisation, the consumption of these compounds during embryonic development of the 3 studied species did not differ markedly from data collected by Clarke et al. (1990), Wehrtmann \& Graeve (1998) and Wehrtmann \& Kattner (1998). The most utilised SFA and MUFA were essentially the same as in all caridean shrimps-16:0 and 18:0, 16:1(n-7), 18:1(n-9) and 
18:1(n-7). The PUFA consumption observed in developing eggs was mainly caused by the utilisation of 18:3(n-3) and 18:2(n-6).

The results concerning the utilisation of FA classes during embryonic development reveal the same trend in all the analysed species. UFA were always used up at a higher rate than SFA, with MUFA being preferentially used for energetic purposes, while HUFA were conserved. Since SFA are non-essential and can be synthesised de novo or obtained by desaturation of MUFA and HUFA (Sargent 1995, 1999), their pattern of consumption may either suggest a selective retainment during embryonic development or a partial utilisation and replacement (turnover).

The changes in the FA profile of Palaemon serratus eggs during embryonic development had been previously analysed by us (Narciso \& Morais 2001). Although a similar trend of FA composition and depletion has been found in the present study, some small differences were encountered. Intraspecific differences have been attributed to female feeding ecology (Biesiot \& Perry 1995), nutritional and physiological condition (Amsler \& George 1984, Hopkins et al. 1993, Wehrtmann \& Kattner 1998), differential demands on resource allocation (Jaeckle 1995), and geographic and seasonal variations in embryonic development (Wehrtmann \& Kattner 1998).

It should be kept in mind that the present study has looked at single populations, at a single moment in time and with no knowledge of the nutritional and physiological condition of the females. Therefore, the lipid and FA composition and utilisation in the eggs should thus be interpreted with some caution.

In conclusion, although the studied species presented some similarities with other caridean shrimp and revealed some homogeneity in the quantitatively most important FA, species-specific differences in their order of magnitude were noticed. In this respect, a higher similarity was observed between Plesionika martia martia and Palaemon serratus eggs, comparatively with Palaemon elegans, probably due to comparable environmental conditions faced by females and newly hatched larvae. On the other hand, the depletion rate of total FA during embryogenesis suggests that $P$. martia martia and $P$. elegans developed a similar adaptive strategy to their early life history, with newly hatched larvae presenting a lower dependence on external energy sources. In the first case, the main catabolic substrate is MUFA while in the second both SFA and MUFA are probably the main energetic fuel available to the newly hatched larvae. Only further work on the lipid embryonic metabolism of different decapod populations at different times of the year, can help clarifying some of the questions raised in this study.
Acknowledgements. Sofia Morais is grateful to IMAR (Institute of Marine Research) for its financial support in the form of a research grant. The authors would also like to thank 4 anonymous reviewers for improving the paper with their comments.

\section{LITERATURE CITED}

Achituv Y, Barnes H (1976) Studies in the biochemistry of cirripede eggs. V. Changes in the general biochemical composition during development of Chthamalus stellatus (Poli). J Exp Mar Biol Ecol 22:263-267

Amsler MO, George RY (1984) Seasonal variation in the biochemical composition of the embryos of Callinectes sapidus Rathbun. J Crustac Biol 4:546-553

Anger K (1998) Patterns of growth and chemical composition in decapod crustacean larvae. Invertebr Reprod Dev 33: 159-176

Barnich R (1996) The larvae of the crustacea decapoda (excl. Brachyura) in the plankton of the French Mediterranean Coast: identification keys and systematic review. Cuvillier Verlag, Göttingen

Berglund A (1980) Niche differentiation between two littoral prawns in Gullmar Fjord, Sweden: Palaemon adspersus and P. squilla. Holarct Ecol 3:111-115

Berglund A, Bengtsson J (1981) Biotic and abiotic factors determining the distribution of two prawn species: Palaemon adspersus and P. squilla. Oecologia 49:300-304

Biesiot PM, Perry HM (1995) Biochemical composition of the deep-sea red crab Chaceon quinquedens (Geryonidae): organic reserves of developing embryos and adults. Mar Biol 124:407-416

Bligh EG, Dyer WJ (1959) A rapid method of total lipid extraction and purification. Can J Biochem Physiol 37: 911-917

Calado R, Narciso L (2002) Camarões e Lagostas da Costa Continental Portuguesa. Prémio do Mar Rei D. Carlos - $6^{\text {a }}$ Edição. Câmara Municipal de Cascais, Cascais, Portugal

Cartes JE (1993) Diets of deep-water pandalid shrimps on the Western Mediterranean slope. Mar Ecol Prog Ser 96: $49-61$

Chapelle S (1986) Aspects of phospholipid metabolism in crustaceans as related to changes in environmental temperatures and salinities. Comp Biochem Physiol 84B: 423-439

Clarke A (1993) Egg size and egg composition in polar shrimps (Caridea; Decapoda). J Exp Mar Biol Ecol 168: 189-203

Clarke A, Brown JH, Holmes LJ (1990) The biochemical composition of eggs from Macrobrachium rosenbergii in relation to embryonic development. Comp Biochem Physiol 96B:505-511

D'Abramo LR, Sheen SS (1993) Polyunsaturated fatty acid nutrition in juvenile freshwater prawn Macrobrachium rosenbergii. Aquaculture 115:63-86

Dall W, Chandumpai A, Smith DM (1993) The fate of some ${ }^{14} \mathrm{C}$-labeled dietary lipids in the tiger prawn Penaeus esculentus. Mar Biol 115:39-45

Dawson RMC, Barnes H (1966) Studies in the biochemistry of cirripede eggs. II. Changes in lipid composition during development of Balanus balanoides and B. balanus. J Mar Biol Assoc UK 46:249-261

Dos Santos A (1999) Larvas de Crustáceos Decápodes ao Largo da Costa Portuguesa. PhD thesis, University of Lisbon

Fincham A (1983) Larval development of British prawns and 
shrimps (Crustacea: Decapoda: Natantia) 4. Palaemon (Palaemon) serratus (Pennant, 1777) and functional morphology of swimming. Bull Brit Mus (Nat Hist) Zool 24: 125-161

Fincham A, Williamson D (1978) Crustacea decapoda: larvae. VI. Caridea, families Palaemonidae and Processidae. Fiches Identif Zooplanct 159/160:1-8

Fox C, Brown JH, Briggs M (1994) The nutrition of prawns and shrimp in aquaculture-a review of recent research. In: Muir JF, Roberts RJ (eds) Recent advances in aquaculture, Vol V. Blackwell Science, Oxford, p 131-206

Harrison KE (1990) The role of nutrition in maturation, reproduction and embryonic development of decapod crustaceans: a review. J Shellfish Res 9:1-28

Herring PJ (1973) Depth distribution of the carotenoid pigments and lipids of some oceanic animals. 2. Decapod crustaceans. J Mar Biol Assoc UK 53:539-562

Herring PJ (1974) Size, density and lipid content of some decapod eggs. Deep-Sea Res 21:91-94

Hopkins CCE, Sargent JR, Nilssen EM (1993) Total lipid content, and lipid and fatty acid composition of the deepwater prawn Pandalus borealis from Balsfjord, northern Norway: growth and feeding relationships. Mar Ecol Prog Ser 96:217-228

Jaeckle WB (1995) Variation in the size, energy content, and biochemical composition of invertebrate eggs: correlates to the mode of larval development. In: McEdward LR (ed) Ecology of marine invertebrate larvae. CRC Press, Boca Raton, FL, p 49-77

Kattner G, Wehrtmann IS, Merck T (1994) Interannual variations of lipids and fatty acids during larval development of Crangon spp. In the German Bight, North Sea. Comp Biochem Physiol 107B:103-110

King MG, Butler AJ (1985) Relationship of life-history patterns to depth in deep-water caridean shrimps (Crustacea: Natantia). Mar Biol 86:129-138

Kurian C (1956) Larvae of decapod crustacea from the Adriatic Sea. Acta Adriat 6(3):1-108

Lagardère J (1971) Les crevettes des côtes du Maroc. Trav Inst Sci Cherifien Fac Sci Ser Zool 36:1-140

Lardies MA, Wehrtmann IS (1996) Aspects of the reproductive biology of Petrolisthes laevigatus (Guérin, 1835) (Decapoda, Anomura, Porcellanidae). Part I: Reproductive output and chemical composition of eggs during embryonic development. Arch Fish Mar Res 43:121-135

Mauchline J (1988) Egg and brood sizes of oceanic pelagic crustaceans. Mar Ecol Prog Ser 43:251-258

McConaugha J (1985) Nutrition and larval growth. In: Wenner AM (ed) Crustacean issues, Vol 2, Larval growth. AA Balkema, Rotterdam, p 127-154

Metcalfe LD, Schmitz AA (1961) The rapid preparation of fatty acid esters for gas chromatography analysis. Anal Chem 33:363-364

Middleditch BS, Missler SR, Ward DG, McVey JP, Brown A, Lawrence AL (1979) Maturation of penaeid shrimp: dietary fatty acids. Proc World Maric Soc 10:472-476

Mileikovsky SA (1971) Types of larval development in marine bottom invertebrates, their distribution and ecological significance: a re-evaluation. Mar Biol 10:193-213

Narciso L (1999) Aquaculture development: perspectives for

Editorial responsibility: Otto Kinne (Editor),

Oldendorf/Luhe, Germany the next decade. In: Beurier JP, Kiss A, Mahmoudi S (eds) New technologies and law of the marine environment. Kluwer Law International, London, p 41-52

Narciso L, Morais S (2001) Fatty acid profile of Palaemon serratus (Palaemonidae) eggs and larvae during embryonic and larval development using different live diets. J Crustac Biol 21:566-575

Nates SF, McKenney CL (2000) Ontogenetic changes in biochemical composition during larval and early postlarval development of Lepidophthalmus louisianensis, a ghost shrimp with abbreviated development. Comp Biochem Physiol 127B:459-468

Pandian TJ (1970a) Ecophysiological studies on the developing eggs and embryos of the European lobster Homarus gammarus. Mar Biol 5:154-167

Pandian TJ (1970b) Yolk utilization and hatching time in the Canadian lobster Homarus americanus. Mar Biol 7: 249-254

Petersen S, Anger K (1997) Chemical and physiological changes during the embryonic development of the spider crab, Hyas araneus L. (Decapoda: Majidae). Comp Biochem Physiol 117B:299-306

Pollock DE, Melville-Smith R (1993) Decapod life histories and reproductive dynamics in relation to oceanography off Southern Africa. S Afr J Mar Sci 13:205-212

Rainuzzo JR, Reitan KI, Olsen Y (1997) The significance of lipids at early stages of marine fish: a review. Aquaculture 155:103-116

Rothlisberg PC, Pearcy WG (1977) An epibenthic sampler used to study the ontogeny of vertical migration of Pandalus jordani (Decapoda, Caridea). Fish Bull US 74:994-997

Sargent JR (1995) Origins and functions of egg lipids: nutritional implications. In: Bromage NR, Roberts RJ (eds) Broodstock management and egg and larval quality. Blackwell Science Publishers, Oxford, p 353-372

Sargent JR, McEvoy LA, Estevez A, Bell G, Bell M, Henderson J, Tocher D (1999) Lipid nutrition of marine fish during early development: current status and future directions. Aquaculture 179:217-229

Turner RL, Lawrence JM (1979) Volume and composition of echinoderm eggs: implications for the use of egg size in life-history models. In: Stancyk SE (ed) Reproductive ecology of marine invertebrates. Belle W. Baruch Library of Marine Science, Vol 9. University of South Carolina Press, Columbia, SC, p 25-40

Udekem d'Acoz C (1999) Inventaire et distribution des crustacés décapodes de l'Atlantique nord-oriental, de la Méditerranée et des eaux continentales adjacentes au nord de $25^{\circ} \mathrm{N}$. Patrimoines naturels (Mus Natl Hist Nat/ Serv Patrimoine Nat) 40:1-383

Wehrtmann IS, Graeve M (1998) Lipid composition and utilization in developing eggs of two tropical marine caridean shrimps (Decapoda: Caridea: Alpheidae: Palaemonidae). Comp Biochem Physiol 121B:457-463

Wehrtmann IS, Kattner G (1998) Changes in volume, biomass, and fatty acids of developing eggs in Nauticaris magellanica (Decapoda: Caridea): a latitudinal comparison. J Crustac Biol 18(3):413-422

Zar JH (1996) Biostatistical analysis. Prentice-Hall, Upper Saddle River, NJ

Submitted: January 28, 2001; Accepted: May 31, 2002

Proofs received from author(s): September 25, 2002 